\title{
Mathematics Special Content Competencies of Elementary School Teachers
}

\author{
Mehmet Gülteke ${ }^{1}$, Ekber Tomul ${ }^{2}$, Fikret Korur ${ }^{2}$ \\ ${ }^{1}$ Elementary Teacher, Manisa, Turkey \\ ${ }^{2}$ Faculty of Education, Department of Elementary Education, Mehmet Akif Ersoy University, Burdur, Turkey \\ Email: etomul@mehmetakif.edu.tr, ekbertomul@gmail.com, fikretkorur@mehmetakif.edu.tr
}

Received October $8^{\text {th }}, 2013$; revised November $8^{\text {th }}, 2013$; accepted November $15^{\text {th }}, 2013$

Copyright (C) 2013 Mehmet Gülteke et al. This is an open access article distributed under the Creative Commons Attribution License, which permits unrestricted use, distribution, and reproduction in any medium, provided the original work is properly cited. In accordance of the Creative Commons Attribution License all Copyrights (C) 2013 are reserved for SCIRP and the owner of the intellectual property Mehmet Gülteke et al. All Copyright $\mathbb{C}$ 2013 are guarded by law and by SCIRP as a guardian.

\begin{abstract}
According to the results of national and international level examinations, the achievement of students in Turkey in mathematics is low. Elementary school teachers play a significant role in the education of students. Elementary school teachers differ from other teachers in that they are responsible for teaching more than one subject. In determining the competencies and performance indicators of elementary school teachers, the Ministry of National Education has paid regard to the common ground and integrating characteristics of the subjects rather than the special content knowledge of each subject. However, owing to the fact that each subject taught by the elementary school teachers necessitates different disciplines and approaches, it is also essential to determine the special content competencies related to the subjects being taught. The objective of this study is to analyze the opinions of elementary school teachers on their mathematical special content competencies. The study group consists of 72 elementary school teachers who are employed in official primary schools in Manisa. The data were collected through questionnaires. The collected raw data were analyzed by content analysis. Mathematics special content competencies of elementary school teachers were grouped under three main categories. These themes are mathematics special content knowledge, knowledge about mathematics teaching and learning as well as confidence, attitude and values regarding mathematics. Teachers' opinions particularly underline the significance of field content knowledge, while laying less weight on associating the program content with daily life and with other subjects. It is observed that the teachers are aware of the information in the written sources; however, they are not fully aware of the process of putting the program content into practice, nor their skills. Some teachers are aware of the fact that it is important to teach mathematics topics and associate them with life, rather than possessing knowledge about mathematics special content at an advanced level. Furthermore, little emphasis is given to "utilizing appropriate measurement-evaluation methods". A great majority of teachers stress keeping the students active and teaching the subject by taking the students' level into account; however, only few make reference to the importance of treating students equally and knowing about the differences among students.
\end{abstract}

Keywords: Elementary School Teacher; Special Content Competencies; Mathematics Competencies

\section{Introduction}

According to examinations carried out at national and international level, the academic achievement of primary school students in Turkey is not at a satisfactory level. Mathematics ranks first among the subjects that students are least successful in the primary and secondary education (Tıraș, 1999). According to PISA 2003 results, the average score of Turkey in mathematics is 423 . This value is 0.75 point below the standard deviation of Organization for Economic Co-operation and Development (OECD) countries (PISA, 2005). Turkey's mathe-

\footnotetext{
"This study is produced from the master's thesis titled "The Analysis of Elementary Teachers' Views Related to Mathematics Special Content Competencies" written by Mehmet GÜLTEKE advised by Assoc. Prof. Dr. Ekber TOMUL from the Social Sciences Institute of Mehmet Akif University.
}

matics achievement score in TIMSS in 2007 is 432, an average score below the evaluation criterion of the exam which is 500 . Considering the overall average of participant countries (450), Turkey again takes the place among countries below the average scores in TIMSS 2007 (TIMSS, 2007). National Student Success Determination Examination (ÖBBS) outcomes are also parallel to international initiatives (ÖBBS, 2005). The results of OKS and SBS examinations carried out from 2001 to 2010 were respectively: the overall average of correct answers out of 25 questions was 2.90 in the first period; and this average was 3.68 out of 20 questions afterwards (Y1lmaz, 2011).

Mathematics education constitutes one of the most important, and even the most important constituent of basic education (Umay, 2003). Learning mathematics is imperative as an area that develops advanced level behaviors and acquisitions such as analyzing, reasoning, communicating, generalizing, creative 
and independent thinking (Çakmak, 1998). When mathematics taught at schools and the mathematics used in the real world are not related to each other, this subject becomes a tool that is solely learned to pass the class, rather than a tool to comprehend and perceive the world (Martin, 2007).

\section{Elementary Teachers' Role in Teaching Mathematics}

One of the most generic definitions of education is the process of encouraging an individual with the desired behavior. The most significant elements of this process are the student, the education program and the teacher. In the course of education, the teacher acts as the element that makes other elements meaningful and has the biggest impact on realization of the education. The teacher is the person who is in continuous interaction with the student, implementing the education program, managing the teaching process and assessing the student as well as the education. The qualifications and competency of the teacher substantially influence these processes (Ministry of National Education-MEB, 1999). In a study covering 50 countries, carried out by Darling-Hammond, the crucial relation between the students' achievement and teachers' qualification is emphasized (quot: Kaplan and Owings, 2002). In the education process, children are influenced by the attitudes and behaviors, reactions, thoughts, opinions, values, world views, habits and emotional responses of their teacher at school and in the classroom environment. Students expect from teachers to give prominence to "paying attention to the opinions of students", "guiding the students through his/her experiences", rather than "pulling rank on students" and "expecting them to study hard" (Lee \& Johnston-Wilder, 2012). In this context, their qualifications become crucial as mathematics teachers in the related literature.

The teachers play the biggest role in eliminating such negative attitude and attaining the desirable achievement in mathematics. The qualities of the teachers play a major role in ensuring that students enjoy mathematics; comprehend mathematics topics and creating an efficient and pleasurable teachinglearning process (Akdemir, 2006: p. 4). Yet, many studies point out the incompetence of teachers for failure in mathematics. Çiftçi (2010) states that the students' failure to attain desirable achievement in mathematics is based on many elements such as the teaching program, teachers, personal lives, and family and financial factors. In the study carried out by Soylu (2009), it is determined that a large majority of "classroom teacher candidates" do not find themselves fully capable of using reform teaching methods and techniques in mathematics subjects. In the study of Türnüklü (2005), which focused on determination of the relation between pedagogical content knowledge and the mathematics content knowledge of mathematics teachers; a correlation was found between the pedagogical content knowledge and the mathematics content knowledge of mathematics teachers. Teacher candidates with high achievement in mathematics were observed to be more competent in taking critical role in the achievement of female students in mathematics and science as perceived by the teachers. The negative attitudes of female students towards mathematics and science subjects as well as their low participation in these subjects are stated to be influenced by the attitude of their teachers (Leach 1994). According to Southwell and Penglase (2005), it is challenging for a teacher who lacks self confidence in his/her mathematics knowledge to provide students with necessary confidence and skills. Therefore, teachers are ought to possess the mathematics special content knowledge to clarify students' questions, to support them in broader thinking, to estimate through which topic a student can reach particular mathematical information, and also to estimate potential misconceptions of students. For instance, in the qualitative study with six academicians, carried out by Park, Güçler and McCrory (2013) on the fractions definition of fractions and teaching the fractions topic, it was demonstrated that even the academicians considered topics such as "fractions" to be easy and they taught the topics superficially and they did not elaborate their definition or usage.

\section{An Overview of Elementary Teachers' Special Content Competencies}

While the significance of the teachers' role in the education process is emphasized in the studies, there are also studies focusing on the competencies of the teachers. The Turkish state planning organization (DPT, 2000) states that an ideal teacher should possess special content knowledge should be informative-instructive and equipped with general cultural competencies. Furthermore, the approach in Teacher Competencies Directive (DPT, 2000) prepared under the coordination of Ministry of National Education, General Directorate for Teacher Training and Education was taken as a basis. According to the referred Directive, teachers should be competent in LearningTeaching, General Knowledge and Skills, and Special Content Knowledge and Skills. In the meeting held on 20-21 June 2005 within the framework of "Education 2010" of the European Union, "Teacher Competency and Qualifications, common European Principles" was addressed in which special content knowledge, pedagogical knowledge, guidance and social, as well as cultural education of teachers were noted with regard to teacher education. The first years of school education forms the basis of preparation of the child to the adulthood; and the knowledge and skills acquired in this period lays the foundations of knowledge and skills to be taught in upper stages of education (Gürkan, 1993). As the foundations of mathematics education are laid down in primary school, classroom teachers undertake a great role in endearing mathematics in a real sense and helping the students comprehend mathematics (Elmas, 2010). A study carried out by Uusimaki and Nason (2004) in Australia demonstrates that the negative opinions and concerns of elementary school teacher candidates related to mathematics subject arise during their primary education (by $66 \%$ ), in secondary education (by $22 \%$ ) and in higher education (by $11 \%$ ).

Elementary school teachers function from the first to fifth grade of primary school in Turkey. These teachers are responsible for providing guidance to students in their class and preparing them to an upper level in addition to teaching the subjects (Saygil1, 2009).

MEB (2002) specifies that elementary school teachers should be competent in various areas including the teaching-learning environment, development, monitoring and evaluation, personal and professional development, the relations with the society, the arts and aesthetics, improving language skills, scientific and technological developments, individual responsibilities and socializing, physical training and security.

MEB (2002) enumerates the knowledge and skills of a teacher related to the subject he/she teaches as follows; thus, the teacher should be capable of

a) Explaining basic information, concepts and principles in 
different forms,

b) Explaining different opinions, theories, teaching methods, study and research methods,

c) Assessing and selecting teaching sources and teaching materials,

d) Making researches and producing information in the field,

e) Utilizing and developing programs to encourage students to ask questions about the special content, to perceive opinions from different perspectives and to produce information,

f) Bringing forth multi-disciplinary teaching experiences that enable student to associate necessary knowledge and skills with other fields,

g) Identifying problems in the field, seeking solutions, selecting, implementing and evaluating the appropriate solution.

\section{The Aim of the Study}

According to the outcomes of examinations carried out at national and international level, the mathematics achievement of students in Turkey is low. Elementary school teachers play a significant role in the education of students. The elementary school teachers differ from other teachers in that they are responsible for teaching more than one subject. This situation requires elementary school teachers to possess competency on the basis of a multi-disciplinary and interdisciplinary understanding. Based on this fact, in determining the competencies and performance indicators of elementary school teachers, MEB (2008) has paid regard to the common ground and integrating characteristics of different subjects, rather than the special content knowledge of each subject taught by the elementary school teacher. However, owing to the fact that each subject taught by the elementary school teachers necessitates different disciplines and approaches, it is also essential to determine the special content competencies related to the subjects being taught. Many studies have been conducted on the special content competency of elementary school teachers, while the competencies of teachers on the subjects they teach remain unknown. Determination of teachers' mathematics special content knowledge and developing suggestions are considered to be important points in terms of contributing to the training of elementary school teachers as well as their mathematics education.

The aim of this study is to identify the opinions of the elementary school teachers regarding their mathematics special content competencies. In line with this general objective, it is aimed to deeply analyze the opinions in terms of the elementary school teachers' "special content knowledge", "knowledge about teaching and learning" as well as their "confidence in, attitudes towards and values regarding mathematics".

\section{Methodology}

\section{Sampling and Population}

The study group of this research was selected among elementary school teachers employed in official primary schools in Manisa Province. 751 elementary school teachers are currently employed in the official primary schools located in Manisa Province. These teachers consist of 303 male, and 448 female teachers. In the study group, 73 elementary school teachers have been selected from various schools in terms of accessible considerations. The researchers were not acquainted with these teachers before the study. The teachers included in this study, were not from one school but different schools in
Manisa Province. At the beginning of the field work, we explained the teachers that any sort of participation in the study would totally be based on voluntariness and that they could withdraw at any time from the study without being subject to any penalty. Certain descriptive information related to characteristics of the study group is given below.

Descriptive Information of the Study Group: $56.2 \%(\mathrm{n}=41)$ of the elementary school teachers are female, while $42.8(n=32)$ of them are male. $21.9 \%(n=16)$ of the elementary school teachers hold an associate diploma, 76.6\% $(n=53)$ of them hold an undergraduate diploma, while $5.5 \%(\mathrm{n}=4)$ of them hold a graduate diploma. $1.4 \%(\mathrm{n}=1)$ of the teachers have been in service for 3 - 5 years, $2.7 \%(\mathrm{n}=2)$ of them for 6 - 10 years, $24.7 \%(\mathrm{n}$ $=18)$ of them for $11-15$ years, $30.1 \%(n=22)$ of them for 16 - 20 years and $41.1 \%(n=30)$ of them for more than 20 years.

\section{Research Design}

The qualitative research covers several research strategies that share certain aspects (Patton, 1987). In this study, content analysis was used to support the findings. In fact, both quantitative and qualitative data analytic techniques are used implicitly in any inductive analysis of qualitative data. The data gathered from questionnaires, field notes or documents can be analyzed through its content and in terms of frequencies. Therefore, even content analysis is a qualitative analytic technique; it includes mostly quantitative calculations and interpretations also. Meanwhile, frequency analysis of some keywords or phrases within a qualitative data is a form of quantitative interpretation of quailtative data, and all qualitative data interpretation is a type of content analysis (Yıldırım \& Şimşek, 2005; Meriam, 1998).

In this study, the content analysis technique was used to determine "Mathematics Special Content Competencies" of elementary school teachers facilitates researchers to study performance of human in an indirect manner (Frankel, Wallen, \& Hyun, 2012). Certain specific information was requested through questionnaires and an inductive analysis was carried out to emerge special content competencies from the data of teachers' answers (Meriam, 1998; Yıldırım \& Şimşek, 2005). The type of qualitative data source is personal documents as stated by Bogdan and Biklen (1998) that include first-person narrative data of individuals' beliefs. The data was analyzed by the suggestions offered by Bogdan and Biklen (1998).

\section{Data Collection Instruments and Process of Data Collection}

A questionnaire and questions prepared by the Ministry of National Education, General Directorate for Teacher Training and Education (ÖYEGM) with a view to determine special content competencies of mathematics teachers at secondary education service was utilized in preparation of the questionnaire forms. The questions used by MEB for determination of special content competencies of secondary education mathematics teachers were adapted by the researcher to identify mathematics special content competencies of elementary school teachers (Alacacı, Çetinkaya \& Erbaş, 2009). The general framework of the form was established and a draft form was prepared by considering 'Mathematics Special Content Competencies' from related literature and incorporating pre-interviews that were carried out with classroom teachers and mathematics teachers. Afterwards, the credibility and any other 
validity issues were considered and determined with respect to the form and the questions in the form. Before the study, the participants were informed via e-mail and/or phone about the overview of the study and available dates were scheduled. Afterwards, the forms were distributed to teachers with appointments. Teachers were asked to fill in the forms in a convenient environment and sufficient time was allocated for this step. Within one week of completion of distribution, the participants' schools were visited and the forms were collected. The participant teachers handwrote their opinions to the questions in the questionnaire forms. No information regarding the identity of the participants was asked in the forms.

\section{Analysis of Qualitative Data}

Raw data was prepared from the opinions and related data obtained from the teachers. Necessary measures were taken to ensure that the text files were correct and complete, and the texts were formatted into final form. The obtained texts were kept and analyzed by the researcher in accordance with study objectives. By nature, the main considerations of the qualitative study are the people; their interactive activities and their feelings or opinions. Therefore, data gathered from the forms posed the main for the analysis of the study. The data was analyzed for all teachers in the same data set, since the opinions and frequency of expressing these opinions were of utmost interest, rather than the identity or personality of teachers. With a view to support reliability in data analysis, a peer examiner, another researcher of this study, read and re-coded all raw data in the data analysis part (Yin, 2009).

Relevant literature was taken into consideration in the analysis of written documents with the forms. In an attempt to ensure confidentiality, the participants were indicated with Teacher (T) abbreviations, and each participant teacher was given a number. Afterwards, data were for coding, content analysis was performed and data was grouped into categories and themes. In the creation of categories and themes, as well as the teacher competencies identified by MEB the related literature were covered.
The codes refer to the national standards that the teacher should pass with respect to special content competencies in this particular study.

Coding of the data into the code key: In this part, the researcher submitted eight data forms and all of the codes to an unbiased appointed expert. The expert (he/she is a graduate from primary school mathematics education with 3 years expertise in his/her profession. He/she has read articles about the topic and possesses sufficient knowledge on this field) and the researcher independently marked each questions in the code key (Gay, 1987). Upon completion of this step, the entered codes were compared and credibility was assessed.

Comparison of codes and credibility: In this step, the researcher and the expert initially entered and coded all of the data. The researcher and the expert calculated the credibility of the research by comparing the codings. In the descriptive analysis, "Consensus" and "Dissidence" numbers were determined from the marks of the researcher and the expert. When the researcher and the expert marked the same theme for a particular question or when neither filled any theme for a particular question, then this was accepted as "consensus between the experts". When the expert and the researcher marked different themes for the same question, then the marking of the researcher was taken as basis; however, this situation was accepted as "dissidence".

Credibility of the research;

$\mathrm{T}($ compromise percentage $)=$

$[\operatorname{Consensus}(\mathrm{Na}) /($ Consensus $(\mathrm{Na})+\operatorname{Dissidence}(\mathrm{Nd}))] \times 100$

was calculated by using the formulation above (Gay, 1987; Miles \& Huberman, 1994). It is stated that credibility between the examiners is established when the outcome, as calculated by the credibility formulation in the literature, is above 70\% (Gay, 1987; Miles \& Huberman, 1994). At this stage after credibility efforts, the credibility percentages of the questions were calculated. The credibility percentages of the questions are presented in Table 1.

Table 1.

Credibility percentages of the questions.

\begin{tabular}{|c|c|c|}
\hline Questions & Themes & Credibility Percentage (\%) \\
\hline \multirow{4}{*}{$\begin{array}{l}\text { To what extent do you think } \\
\text { a good elementary school teacher } \\
\text { possess mathematics knowledge? }\end{array}$} & $\begin{array}{l}\text { In depth knowledge about primary school mathematics curriculum } \\
\text { and relevant advanced level mathematics topics }\end{array}$ & 86.2 \\
\hline & $\begin{array}{l}\text { Knowledge about how to implement basic topics and concepts } \\
\text { of the primary school curriculum in the real life. }\end{array}$ & 83.3 \\
\hline & $\begin{array}{l}\text { Knowledge about and modeling the correlation between the basic } \\
\text { concepts and topics in mathematics with other disciplines }\end{array}$ & 100 \\
\hline & Knowledge about mathematical processes. & 100 \\
\hline \multirow{5}{*}{$\begin{array}{l}\text { To what extent a good elementary school } \\
\text { teacher possess knowledge about } \\
\text { teaching-learning mathematics? }\end{array}$} & Ability to create the suitable environment for learning in mathematics subject & 100 \\
\hline & $\begin{array}{l}\text { Ability to make use of appropriate sources, materials and } \\
\text { technologies in mathematics teaching }\end{array}$ & 92.3 \\
\hline & Ability to utilize appropriate methods and techniques in mathematics teaching & 96 \\
\hline & Ability to identify and monitor mathematics level of students & 100 \\
\hline & $\begin{array}{l}\text { Ability to make use of measurement and evaluation techniques } \\
\text { in mathematics teaching }\end{array}$ & 100 \\
\hline \multirow{3}{*}{$\begin{array}{l}\text { What should be the attitude and approach } \\
\text { of a good elementary school teacher } \\
\text { towards teaching-learning mathematics? }\end{array}$} & $\begin{array}{l}\text { Possessing positive attitudes towards, confidence in and values } \\
\text { regarding mathematics }\end{array}$ & 88.8 \\
\hline & $\begin{array}{l}\text { Possessing positive attitudes to, confidence in and values } \\
\text { regarding mathematics teaching process }\end{array}$ & 96.5 \\
\hline & $\begin{array}{l}\text { Possessing positive attitudes to, confidence in and values } \\
\text { regarding mathematics learning process. }\end{array}$ & 95.2 \\
\hline
\end{tabular}


As can be observed from Table 1, the credibility percentages obtained as a result of comparison of questions' coding by the researcher and the expert, vary between $83.3 \%$ and $100 \%$. Meanwhile, the average credibility for the coding of questions in the study was calculated as $95.9 \%$. With these outcomes above $70 \%$, the answers of the research can be considered to have been credibly coded (Gay, 1987; Miles \& Huberman, 1994).

After the qualitative data analysis, the opinions obtained from participants and relevant literature were taken into consideration and categories were created by means of analysis of opinions of these elementary school teachers regarding their mathematics special content competencies. The categories were grouped as themes, and participant expressions related to these themes as well as their frequencies were indicated.

\section{Results}

Content analysis of the obtained raw data is collectively presented in Table 2. According to Table 2, the mathematics special content knowledge of elementary school teachers is concentrated in three main categories. These areas are "mathematics special content knowledge", "knowledge about teachinglearning mathematics", "the attitudes to", "confidence in and values regarding mathematics". Mathematics special content knowledge is divided into four sub-sections; knowledge about teaching-learning mathematics is divided into six sub-sections; while the attitudes to, confidence in and values regarding mathematics theme is divided into three sub-sections (frequency of detected themes was presented with ' $\mathrm{f}$ ').

Table 2.

Mathematics special content competencies of elementary school teachers.

\begin{tabular}{|c|c|c|c|}
\hline Categ. & Themes & Standards (used as codes) & $\mathrm{f}$ \\
\hline \multirow{4}{*}{ 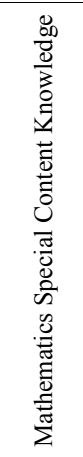 } & $\begin{array}{l}\text { In depth knowledge about primary } \\
\text { school mathematics curriculum } \\
\text { and relevant advanced level } \\
\text { mathematics topics }\end{array}$ & $\begin{array}{l}\text { To know the concepts, definitions, principles and theorems } \\
\text { in mathematics subject contents. } \\
\text { Knowledge of mathematics at a more advanced level than } \\
\text { primary school mathematics curriculum. } \\
\text { To know about the correlations among topics and concepts } \\
\text { in mathematics. }\end{array}$ & 22 \\
\hline & $\begin{array}{l}\text { Knowledge about how to implement } \\
\text { basic topics and concepts of the primary } \\
\text { school curriculum in the real life. }\end{array}$ & $\begin{array}{l}\text { To know about the correlation between the topics and } \\
\text { concepts in mathematics and their practice in the daily life. }\end{array}$ & 5 \\
\hline & $\begin{array}{l}\text { Knowledge about and modeling the correlation } \\
\text { between the basic concepts and topics in } \\
\text { mathematics with other disciplines }\end{array}$ & $\begin{array}{l}\text { To know about the relation of mathematics with other subject fields (disciplines). } \\
\text { To know and interpret the modeling of physical, social and mathematical } \\
\text { phenomena and their different ways of demonstration. }\end{array}$ & 5 \\
\hline & $\begin{array}{l}\text { Knowledge about mathematical } \\
\text { processes. }\end{array}$ & $\begin{array}{l}\text { To know about selecting and expressing mathematical problems. } \\
\text { To know more than one way of solving mathematical problems. }\end{array}$ & 17 \\
\hline \multirow{5}{*}{ 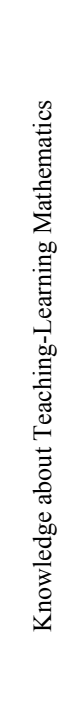 } & $\begin{array}{l}\text { Knowledge about basic concepts } \\
\text { related to mathematics teaching, } \\
\text { and ability to plan mathematics } \\
\text { learning process. }\end{array}$ & $\begin{array}{l}\text { To plan in detail the content of the subject and how the subject will be taught. } \\
\text { To teach mathematics from easy to difficult levels. } \\
\text { To teach the topics from concrete to abstract levels. } \\
\text { To know which topics the students may have difficulty in understanding. }\end{array}$ & 17 \\
\hline & $\begin{array}{l}\text { Ability to create the suitable } \\
\text { environment for learning in } \\
\text { mathematics subject }\end{array}$ & $\begin{array}{l}\text { To make the subject more enjoyable to ensure student participation into the subject. } \\
\text { To take into consideration the level of students while explaining the subject. } \\
\text { To keep the students active during the subject. } \\
\text { To make use of examples from daily life in teaching the subject. }\end{array}$ & 35 \\
\hline & $\begin{array}{l}\text { Ability to make use of appropriate sources, materials } \\
\text { and technologies in mathematics teaching }\end{array}$ & $\begin{array}{l}\text { To utilize various materials and recently published books. } \\
\text { To make use of information and communication technologies during teaching. }\end{array}$ & 12 \\
\hline & $\begin{array}{l}\text { Ability to utilize appropriate } \\
\text { methods and techniques in } \\
\text { mathematics teaching }\end{array}$ & $\begin{array}{l}\text { To solve plenty of questions/problems/examples. } \\
\text { To explain the subject in a clear and comprehensible language and in an } \\
\text { apprehensible manner. } \\
\text { To utilize various and effective methods to ensure that students } \\
\text { understand the subject. } \\
\text { To teach with figures and visual sources. }\end{array}$ & 23 \\
\hline & $\begin{array}{l}\text { Ability to identify and monitor } \\
\text { mathematics level of students }\end{array}$ & $\begin{array}{l}\text { To explain the subject in line with the students' level, comes down to students' level. } \\
\text { To know the students; know about their pace of learning, attention, willingness, } \\
\text { academic capacities and targets. }\end{array}$ & 12 \\
\hline 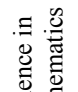 & $\begin{array}{l}\text { Possessing positive attitudes to, confidence } \\
\text { in and values regarding mathematics }\end{array}$ & $\begin{array}{l}\text { Personally enjoys mathematics. } \\
\text { To make sure that students enjoy mathematics. }\end{array}$ & 17 \\
\hline 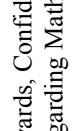 & $\begin{array}{l}\text { Possessing positive attitudes to, } \\
\text { confidence in and values regarding } \\
\text { mathematics teaching process }\end{array}$ & $\begin{array}{l}\text { To like teaching mathematics. } \\
\text { To act equally, honest and fair in the classroom. } \\
\text { To ensure active participation of students in the subject. } \\
\text { To teach the subjects by taking into consideration the level of students. }\end{array}$ & 26 \\
\hline 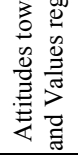 & $\begin{array}{l}\text { Possessing positive attitudes to, } \\
\text { confidence in and values regarding } \\
\text { mathematics learning process. }\end{array}$ & $\begin{array}{l}\text { To make students like mathematics, assist them in overcoming their fear of mathematics. } \\
\text { To exert efforts to increase the achievement of students who are less successful. } \\
\text { To believe that every student can achieve achievement in mathematics, and } \\
\text { exerts efforts accordingly. } \\
\text { To know about the personal differences among students. }\end{array}$ & 17 \\
\hline
\end{tabular}


In Table 2 regarding mathematics special content competency of elementary school teachers; the most frequent opinions discovered were in depth knowledge about primary school mathematics curriculum and advanced level mathematics topics ( $\mathrm{f}=28$ ), creating a suitable environment for learning mathematics subject $(\mathrm{f}=30)$; utilizing appropriate methods and techniques in mathematic teaching $(f=24)$; possessing positive attitudes to, confidence in and values regarding mathematic teaching process $(f=29)$; possessing positive attitudes to, confidence in and values regarding mathematics learning process ( $\mathrm{f}$ $=21$ ); ability for self-evaluation and professional development ( $\mathrm{f}=84$ ). According to the these opinions, teachers' possessing positive attitudes through teaching and learning mathematics, possessing mathematics knowledge were more frequently emphasized then their adjusting the concepts to students' levels planning teaching and learning process or possess makes or confidence in regarding mathematics.

\section{Mathematics Special Content Knowledge}

The participating elementary school teachers are in the opinion that they need mathematics special content information in "in depth knowledge of the curriculum and relevant advanced level mathematics topics", "knowledge on how to implement the basic topics and concepts in the real life", "knowledge on the correlation of and modeling the basic concepts and topics in mathematics with the other disciplines", and "knowledge on mathematical processes".

Elementary school teachers lay a strong emphasis on the need for in-depth knowledge of the curriculum and relevant mathematics topics in their explanations. Three of teacher indicated that "Teachers should have full command of the primary school topics" (T1), "Teachers should know to a good extent the topic and concepts related to mathematics subject, know the order and development of relations among concepts, and implement it" (T2), "Teachers should possess above-primary school level mathematical knowledge" (T3).

A group of teachers from the participants wrote that "There is no need for an advanced level of mathematics knowledge, knowing 5th grade curriculum would be sufficient" (T12), "The knowledge should be at a level that would suffice to the class, to which the teacher teaches" (T13), "Knowing a good level of mathematics is unnecessary for a good elementary school teacher, teacher should come down to the level of students" (T.8), asserting that it is not very important to have knowledge of topics more advanced than the curriculum; what is important is their behavior and their ability to manifest the knowledge. However, another group of participants emphasized the importance of knowledge of elementary school teachers related to mathematics curriculum, and asserted that they should possess greater knowledge than the curriculum requires (T.30,31,36, 42,46,62,67).

The explanations of participants; "Teacher should know the relations of different mathematics topics and concepts well" (T16), "Teachers should know the development of, and order of relations among topics and concepts of mathematics well, and possess the skills to implement them" (T17), "Teachers should know the first to fifth grade curriculum, the relations between the concepts and topics of mathematics well" (T40), "Teachers should know the concepts and topics of mathematics, and the relation among them well" (T40), "Teachers should know the relation among different mathematics topics and concepts"
(T45), "Teachers should know numbers, geometric figures, measurements and the relations among the topics" (T60), put forward that elementary school teachers should know the topics and concepts in mathematics, as well as the relation among them.

One of the themes that the participants accentuated is that the elementary school teachers "should possess knowledge on mathematical processes". This theme is generally based on determining, putting forward mathematical problems and having more than one way of solving these problems. Participants expressed that "Teachers should focus on solving mathematical problems, and channel students into thinking" (T5), "Teacher should have inclination towards problem solving and analytical thinking" (T18), "Teacher should pay attention to creating and solving problems" (T69), with regard to determination of and putting forward mathematical problems; "Teacher should teach alternative ways of solution" (T3), "Teachers should be capable of expressing mathematical thoughts via different opinions and interpretations, should channel the student into thinking, and provide proofs by alternative ways" (T15), "Teacher should know the variety of new learning ways, and should have the capacity to go beyond traditional methods" (T54), with regard to the fact that elementary school teachers should know the multiple solution ways of problems.

When the opinions of teachers are analyzed, it is observed that a strong emphasis is given particularly in the importance of special content information, while less emphasis is given to associating the program content with daily life and other subjects. It is observed that the teachers are aware of the instructions of written sources; however, they are not aware of the processes and their skills related to putting the program content into practice.

Questions asked in the examinations carried out at international level such as PISA and TIMMS address the practice of mathematics in daily life. The fact that few teachers expressed opinion about implementation of mathematics in daily life is considered to demonstrate the insufficiency of teachers in this regard. According to Aydemir (2008), an efficient teacher should know the main concepts of the subject he/she teaches, convey the information to students by acknowledging different perspectives as well, and forge a strong link between the information taught and daily life at the same time.

\section{Knowledge of Teaching-Learning Mathematics}

Participants stated that regarding teaching-learning mathematics, the elementary school teachers needed to possess competency in "knowing basic concepts and planning teaching process", "creating a suitable environment for teaching", "utilizing appropriate sources, materials and technologies", "identifying and monitoring the mathematics level of students" and "utilizing measurement and evaluation techniques".

The opinions of the participants regarding possessing knowledge about the basic concepts on learning mathematics and planning mathematics learning process may be summarized as "The concepts should elaborately plan the subject content and how it would be taught; teaching mathematics from easy to difficult levels; the topics should be taught from concrete to abstract level; and teacher should know which topics would be challenging for the students to comprehend" (T17).

There is a relation between realization of a quality education and planning of the learning conditions as good as possible. 
Attaining the demanded targets in their subjects is dependent on planned preparation of the activities. Participants expressed their opinions in this regard as "Teacher should possess good planning knowledge" (T20), "Teachers should elaborately plan the content of the subject and how she/he would teach it", while another teacher said "Teacher should plan the subject content, identify the topics that are challenging, and ensure active participation in the subject" (T24).

Furthermore the participants stated that "Teacher should know the level and thinking capacity of the student" (T5), "Teacher should teach a subject that is compatible with the level of the student" (T9), "Teacher should know the level of students and teach the subject accordingly" (T10). On the other hand (T18) points out that mathematics education should be compatible with the developmental characteristics of the student by stating that "The education should be compatible with the developmental phase of the child. If the child is at a low level, it should be identified and taught accordingly". Meanwhile, (T59) states that "The teaching should be fit for the students' level, in terms of being easy and clear, as well as concrete". Taking into consideration the level of students in subject teaching is mentioned in "Teacher should determine the mathematics topics in which students suffer difficulties, and teach mathematics by coming down to their level" (T60).

Teachers point out the necessity for teaching in line with the student level. The participants opinions regarding this issue are as follows: "Mathematics teaching should be from concrete to abstract; based on problem solving, establishing relations between topics and concepts by reasoning." (T2), "It should include concrete examples" (T8), "Teacher should teach the subject by practicing-experiencing, trying, using it in their lives" (T29), and "Teacher should know how to turn the topics into interesting and comprehensible ones in the easiest way" (T32).

A subject can be effectively and efficiently realized when the teacher determines the objective of the subject, the learning activities that would enable attaining these objectives, the materials and time to be used, and the measurement - evaluation activities to be applied before teaching the subject. Planning of the education is necessary for a qualified and successful education. These are underscored in the expressions: "Teachers should come down to the level of the students in the topics and concepts they have difficulty" (T16), "Teachers should identify the topics that are challenging in the subject, and ensure active participation in the subject" (T24), "Teachers should determine the topics students have difficulty in mathematics and teach mathematics by coming down to their level" (T60).

Participants emphasized making the subject enjoyable to ensure participation in the subject by stating that "Teachers should make the subject enjoyable to ensure participation in the subject, at the same time should give examples that would teach the topic" (T3), "Teachers should give the information practically, and make the subject enjoyable" (T15), "Teachers should teach mathematics in an entertaining way, should not bore the students when teaching the subject" (T38). "Teacher should know the students' level and teach the subject accordingly" (T10); They kept the students active in the subject by stating that "Teacher should make the student active in the subject" (T9), "Active participation should be ensured in the subject" (T24), "Teacher should teach by practicing-experiencing, trying, using it in his/her daily life in the easiest way" (T29). They emphasized the importance of using examples from daily life in the subject by stating that "The teacher should be capable of conveying that mathematics is a fact of life" (T2). Participants took into consideration the level of students by stating that "Teachers should know the level and thinking capacity of the student", "make use of time with activities that are compatible with the daily life" (T5), "The examples in the subject should be related to current events" (T9).

According to the participants, the elementary school teacher should be capable of utilizing appropriate methods and techniques in mathematics education by solving plenty of questions/problems/examples, by explaining the subject with a clear and comprehensible language and an apprehensible manner, making use of different and effective methods to ensure that students understand, and utilizing figures and visual sources.

The participants state that in mathematics education the teacher should "make the subject enjoyable to ensure participation in the subject, while capable of solving a large number of questions to teach the topic" (T3), "conduct various activities in the class, and explain the subject with examples" (T7), "support his/her knowledge with examples from life" (T10) with regard to solving plenty of questions/problems/examples; "Teacher should use a simple language and figures, graphics and teach the course by having students practice" (T35), "Teacher should teach the subject with a language level comprehensible to the students" (T69), "Elementary school teacher should improve the elocution" (T4) with regard to explaining the subject with a clear and understandable language; "Teacher should identify the challenging topics in the subject, ensure active participation in the subject, make use of appropriate education methods" (T24), "Teacher should teach compatibly with the child's level, and know teaching techniques well" (T25). "Teacher should know well method and techniques, to use what, where and how" $(\mathrm{T} 46, .53,55)$ with regard to utilizing different and efficient methods; "Teacher should enrich the teaching topics with visual materials, and practice plentifully" (T6), "Teacher should use a simple language and figures, graphics and teach the course by having students practice" (T35), "Teacher should come down to the level of students, be capable of utilizing figures and visual materials in the subjects" (T40) with regard to enriching the subject teaching through figures and visual methods.

In examinations, at international and especially at national level, the questions were asked in the aim of measuring various skills. Only very few teachers participating in the study emphasized the ability to use appropriate measurement-evaluation techniques. This situation may be associated with the unsuccessful scores the students get in Turkey.

Teachers evaluate the performance of the students. Striving for an upper level motivates children. At the evaluation stage, teachers have two major duties: to decide on the achievement of students and to the efficiency of the implemented program (Sünbül, 1996). Some teachers emphasize the importance of knowing alternative measurement-evaluation methods, while some others emphasize that examinations, as a different aspect, should be seen as a chance for students to enjoy achievement.

\section{Attitudes to Confidence in and Values Regarding Mathematics}

Participants have stated that it is necessary to possess positive attitudes to, confidence in and values regarding "the field of mathematics", "mathematics teaching process" and "mathematics learning process". The participants may be considered to 
have reached a consensus that a good elementary school teacher should first enjoy mathematics personally, and possess positive attitudes to, confidence in and values regarding mathematics to make the subject enjoyable for the students.

Participants emphasized the interest of the teacher in mathematics by stating that "Teacher should enjoy the subject and manifest to the students that she/he enjoys the subject" (T4), "When the teacher teaches mathematics enthusiastically, then the students will be enthusiastic too" (T14). One teacher stated that (T54), "Teacher should like mathematics, he/she must be comfortable with teaching the subject and reflect it to students" noting the importance of interest of the teacher in mathematics; "Teacher should make students like mathematics" (T1), "Teacher should organize activities that make mathematics enjoyable, and ensure that students comprehend how necessary mathematics is in the daily life" (T9). Teachers also lay emphasis on the positive attitudes to, confidence in and values regarding mathematics by stating that "Teacher should make the subject more enjoyable, and not bore the students" (T23), "Teacher should make the subject enjoyable, and make the subject fun, avoiding causing fears in the students" (T30).

Concerning the mathematics teaching process of elementary school teachers, the participants may be considered to be in consensus about particular attitudes and values such as the need to (a) like teaching mathematics, (b) act equally, fairly and honestly in the class, (c) ensure active participation of the students in the subject, (d) teach the course in accordance with the level of students.

Participants emphasized the importance of liking teaching mathematics by expressing that "Teacher should be enthusiastic, attract the attention of children, by using interesting methods and techniques to make the subject enjoyable" (T20), "Teacher should be affectionate and sincere" (T21); the importance of acting equally, fair and honestly by "Teacher should act equally, honestly and fairly" (T3), "Teacher should act equally to each student, and give a chance to each student" (T17), "Teacher should give each student equal chance for achievement" (T46); the importance of ensuring active participation of students in the subject by stating that "Teacher should teach that it is not a subject to be feared of, by activities such as plays, songs ...etc. compatible with the students' level" (T65); and teaching the subject by taking into consideration the students' level by stating that "Teacher should engage in activities according to the level of the class" (T.10), "Teacher should carry out activities according to the level of the class" (T10), "Teacher should give a chance to every student to ensure their progress and participate in the subject at their level" (T13).

The participants laid emphasis on the positive attitudes to, confidence in and values of a qualified elementary school teacher regarding mathematics learning process, such as the need to (a) make students like mathematics, and assist them in overcoming their fear of mathematics, (b) exert efforts in increasing the achievement of students less successful, (c) believe in that every student can achieve achievement in mathematics and work accordingly, (d) know the personal differences among students.

The participants emphasized the importance of making students like mathematics and assisting them in overcoming the fear of mathematics by stating that "Teacher should make students like mathematics" (T1), "Teacher should organize activities to make mathematics enjoyable. She/he should make students comprehend how necessary mathematics is in the daily life" (T9), "Teacher should know the class, and teach the subject in an entertaining, interesting way compatible with the level" (T26); importance of exerting efforts to increase the achievement of students with less achievement by stating that "Teacher should monitor the level of learning in the class, and ensure unity by taking necessary measures" (T3), "Teacher should present the subject in an apprehensible way by making use of narratives, drama...etc. for students at lower levels" (T26), "Teacher should identify the subjects which students cannot comprehend, and apply different methods for them" (T52), "Teachers should be aware of and apply alternative methods to eliminate the difficulties in challenging topics and concepts" (T62); believing in that every student can achieve success in mathematics, and working towards this end by stating that "Teacher believes in that every student can be successful, and exerts efforts accordingly" $(T 16,62)$, "Mathematics is a subject that can be learnt by anyone" (T29), "Teacher should give a chance to each student, and make each student believe that she/he can be successful" (T30); knowing personal differences among students by stating that "Teacher should know that the way of learning will be unique for each student, and be aware that students may have different types of intelligences, and should not expect the same achievement from every student" (T6).

When the teachers' opinions were analyzed, it is observed that they emphasize teaching the subject by keeping students active in the subject and taking into consideration the level of the students, in particular, while they place less emphasis in treating students equally and knowing the differences among students. It has been observed that teachers in general possess positive attitudes towards mathematics; however, they are not aware of the process of equipping students with positive attitudes towards mathematics.

Some elementary school teachers point out the importance of the fact that teacher should personally like mathematics; while some teachers note the importance of ensuring that students like mathematics. Teachers stated that a teacher should first enjoy mathematics personally to make students like mathematics. According to Harman and Akın (2006), there is a close correlation between the attitudes of elementary school teachers towards mathematics and their achievement in teaching it. The attitudes influence learning, and learning influence the success in teaching process.

Elementary school teachers, who serve in primary schools, which is the foundation of mathematics education, assume a great role in this regard (Yürekli, 2008). According to elementary school teachers, a teacher should attain active participation in the subject, act affectionately and sincerely. Some teachers point out the significance of teaching the subject by taking into account the students' level, while others mention about the importance of enjoying teaching mathematics. Supportive of this finding, Lee and Johnston-Wilder (2012) stated the importance of understanding students' ways of learning mathematics, adjusting the topics according to their level, and asserted that giving a chance to improve their learning would be efficient in learning mathematics.

\section{Conclusions}

Elementary school teachers expressed their opinions under the categories of special content knowledge, knowledge on teaching and learning mathematics, confidence, attitudes in and 
values regarding mathematics. Mathematics special content competencies of elementary school teachers are grouped under three main categories, which are "mathematics special content knowledge", "knowledge about mathematics teaching and learning as well as confidence" and "attitude and values regarding mathematics". It is observed that the teachers are aware of the information in the written sources; however, they are not fully aware of the process of putting the program content into practice, nor their skills. Some teachers are aware of the fact that it is important to teach mathematics topics and associate them with life, rather than possessing knowledge about mathematics special content at an advanced level.

Although mathematics is an abstract subject in general, the education given by elementary school teachers focuses on a tangible stage. Few teachers are aware of the fact that it is more important to teach mathematics topics and associate them with life, rather than possessing advanced level of mathematics special content information. Mathematics problems asked in international examinations such as PISA and TIMMS are based on associations of mathematics with the daily life. This situation may be put forward as one of the reasons of failure of students in Turkey in international examinations.

Teachers are aware of the fact that it is important to plan the content of the subject as well as how to teach the subject in detail, explaining mathematics from easy to difficult levels and from concrete to abstract topics, taking into consideration the level of students in teaching the subject, keeping students active in the subject, making the subject more enjoyable to ensure student participation in the subject and utilizing examples from daily life in the subject.

A large proportion of teachers emphasize keeping students active and teaching the subject by taking into account the level of students, while few mentioned about the importance of treating students equally and being conscious of the differences among students.

Teachers put emphasis on making mathematics more endearing for students, assisting students in overcoming their fear of mathematics, knowing and taking into consideration the personal differences among students, exerting efforts to increase the achievement of students who are less successful in mathematics and believing in that every student can achieve success in mathematics and work towards this success.

\section{REFERENCES}

Akdemir, Ö. (2006). Elementary students' attitudes towards mathematics lesson and achievement motivation. Unpublished Master Thesis, İzmir: Institute of Educational Sciences, Dokuz Eylül University.

Akyüz, G., \& Pala, N. M. (2010). The effect of student and class characteristics on mathematics literacy and problem solving in PISA 2003. İlköğretim Online, 9, 668-678.

Alacacı, C., Çetinkaya, B., \& Erbaş, K. (2009). Second Cycle Report of Commission of Special Content Competencies. Ankara: Ministry of National Education of Turkey-General Directorate of Teacher Improvement and Education.

Arun, Ö. (1998). Factors affecting mathematics achievement. Unpublished Master Thesis, Ankara: Hacettepe University.

Bogdan, R., \& Biklen, S. K. (1998). Qualitative research for education: An introduction to theory and methods (3rd ed.). Boston: Allyn \& Bacon.

Çakmak, Z. (1998). Teaching of progressive mathematics and effective analysis. Anadolu Üniversitesi Ë̆itim Fakültesi Dergisi, 8, 82-92.

Çiftçi, Ş. K. (2010). Issues that primary school teachers face in mathematic instruction in rural communities. Unpublished Master Thesis,
Eskişehir: Institute of Social Sciences, Osmangazi University.

DPT (2000). Higher education-special expertise commission report. 8th Development Five Years Plan, Ankara.

EARGED (2003). Third Studies on Mathematics and Science: National Report. Ankara: Ministry of National Education.

EARGED (2005). National Final Report on Project of PISA 2003, Ankara: Ministry of National Education.

Elmas, S. H. (2010). Level of anxiety and factors causing the anxiety through mathematics teaching of prospective elementary teachers. Unpublished Master Thesis, Afyonkarahisar: Afyon Kocatepe University.

Ersoy, Y. (1993). Information age and mathematics teaching: Transformations and new trends. MESEM-93, ODTÜ, Ankara, 21-22 May 1993.

Ersoy, Y. (2003). Mathematics Literacy I: Objectives, Skills and Competencies. http://www.matder.org.tr

Ersoy, Y. (2006). Innovations in mathematics curricula of elementary schools-I: Objective, content and acquisition. İlköğretim Online, 5, 30-44.

Fraenkel, J. R., Wallen, N. E., \& Hyun, H. H. (2012). How to design and evaluate research in education (8th ed.). New York: Mc Graw Hill.

Gay, L. R. (1987). Educational research competencies for analysis and application (3rd ed.). London: Merrill Publishing Company.

Gürkan, T. (1993). Relation between teacher attitudes and concept of self-respect elementary teachers. Ankara: Sevinç Publications.

Harman, A., \& Akın, M. F. (2006). An evaluation of mathematics teaching style by students of education faculties. Elektronik Sosyal Bilimleri Dergisi, 5, 124-130.

Kaplan, L. S., \& Owings, W.A. (2002). Enhancing teaching quality. Phi Delta Kappa Fastbacks, 499, 3-44.

Lee, C., \& Johnston-Wilder, S. (2012). Learning mathematics-letting the pupils have their say. Educational Studies in Mathematics, 83, 163-180. http://dx.doi.org/10.1007/s10649-012-9445-3

Martin, H. (2007). Mathematical literacy. Principal Leadership ProQuest Education Journal, 7, 28.

MEB (1992). Coordination in teacher education. Ankara: Publication of DAYM.

MEB (1999). Teachers' Competencies Commission Studies (Draft). Ankara: Ministry of National Education of Turkey-General Directorate of Teacher Improvement and Education.

MEB (2002). Teachers' competencies. Ankara: Milli Eğitim Publications.

MEB (2005). Elementary mathematics lesson teaching program and guide. Ankara: Directorate of State Books.

MEB (2006). Teaching profession general competencies. Ankara: Ministry of National Education of Turkey-General Directorate of Teacher Improvement and Education. http://otmg.meb.gov.tr.

MEB (2008). Elementary School Teachers Special Content Competencies. Ankara: Ministry of National Education of Turkey-General Directorate of Teacher Improvement and Education.

Meriam, S. B. (1998). Qualitative research and case study applications in education. California: Jossey-Bass Inc.

Miles, M. B., \& Huberman, M. A. (1994). An expanded sourcebook qualitative data analysis. London: Sage Publication.

OECD (2003). The Pisa 2003 Assessment Framework: Mathematics, reading, science and problem solving knowledge and skills. Paris: OECD Publications.

OECD (2004). Learning for tomorrow's world: First results from PISA 2003. Paris: OECD.

OECD (2006). Assessing scientific, reading and mathematical literacy: A framework for PISA 2006. http://www.pisa.oecd.org

OECD (2007). PISA 2006 science competencies for tomorrow's world. http://www.pisa.oecd.org

ÖBBS (2005). ÖBBS-2005, Mathematics Report, May-2007. Ankara: Ministry of National Education.

Park J., Güçler B., \& McCrory R. (2013). Teaching prospective teachers about fractions: Historical and pedagogical perspective. Educational Studies in Mathematics, 82, 455-479.

http://dx.doi.org/10.1007/s10649-012-9440-8

Patton, M. Q. (1987). How to use qualitative methods in evaluation. California: Sage Publications. 


\section{GÜLTEKE ET AL.}

PISA (2005). PISA national final report. Ankara: Publications of EAR GED.

Sayg11, E. (2009). Adequacy of primary school teachers who are assigned to out of the field, first reading and writing education: Sample of Malatya Province. Unpublished Master Thesis, Malatya: Institute of Social Sciences, İnönü University.

Soylu, Y. (2009). A study on elementary school teachers competencies on ability to use methods and techniques in mathematics lessons. Mersin Üniversitesi Eğitim Fakültesi Dergisi, 5, 1-16.

TIMSS (2007). TIMSS 2007 Report of Turkey. Ankara: Publications of EARGED.

Tıraș, S. (1999). Competencies and level of being effective in terms of Teaching-learning of mathematics teachers. Buca Eğitim Fakültesi Dergisi, İzmir: Dokuz Eylül University.

Türnüklü, E. B. (2005). The relationship between pedagogical and mathematical content knowledge of pre-service mathematics teachers.
Eurasian Journal of Educational Research, 5, 234-247.

Umay, A. (2003). Mathematical reasoning ability. Hacettepe Üniversitesi Eğitim Fakültesi Dergisi, 24, 234-243.

Yıldırım, C. (2004). Thinking mathematics (4th ed.). İstanbul: Remzi Publicaitons.

Yıldırım, A., \& Simsek, H. (2005). Qualitative research methods in social sciences $\left(5^{\text {th }}\right.$ ed.). Ankara: Seçkin Publicaitons.

Yilmaz, A. (2011). An Evaluation between OKS-SBS exams and PISA applications from 2001 to 2010. Bilim ve Aklın Aydinlı̆̆ında Eğitim, $134,80-86$.

Yin, R. K. (2009). Case study research: Design and methods (4th ed.). California: Sage Publications.

Yürekli, Ü. B. (2008). The relationship between pre-service elementary school teachers' self-efficacy perceptions and attitudes towards mathematics. Unpublished Master Thesis, Denizli: Institute of Social Sciences, Pamukkale University. 